$$
\begin{aligned}
& \$ 561 \\
& . C 35
\end{aligned}
$$


S 561

. 035

Copy 1

\title{
FARM EFFICIENCY
}

\section{How lt Depends on Efficient Equipment} For Living

\author{
BY \\ XENOPHON CAVERNO
}

The American farm is the basis of national safety as well as prosperity. To betray the American farmer, through avarice or ignorance, is treason to the United States. 


$$
S^{5 b^{1}} c^{3}
$$

$\because$ 


\section{N T R O D U C T I O N}

This pamphlet, which is a reprint from the "Transactions of The American Society of Agricultural Engineers" for 1915, had its beginnings in a plan to use the ideas it contained as an introduction to a set of bulletins describing certain mechanical equipment which I had designed and manufactured to cover the field indicated by the title.

While it was still in the formative state I began sending it out in response to the almost continuous calls for information along this line which come from agricultural colleges, extension departments, and various other agencies, which are trying to help establish better farm methods. This policy resulted in a great deal of correspondence and many personal interviews and in a continuous enlargement of the scope of the paper.

In the spring of 1915 I presented the subject to the County Agricultural Advisors of the State of North Dakota at their annual convention at Fargo, and in the following summer to the students at the Summer School of Agriculture at the University of Wisconsin. The questions asked at these meetings and the discussions aroused resulted in still more additions to the subjects covered and to the gradual beating of the material into its present shape.

Very early in this process I became convinced that there was a great dearth of knowledge in this particular line and that more or less by accident I had gone through a training and experience which fitted me to fill the gap. Hence the cutting out of everything that might cast the shadow of commercialism over the material itself or the method of putting it into circulation.

As I cannot go everywhere and preach the gospel of better farm living, I have tried to put the conclusions resulting from my experiences along this line into the form of a suggestive outline, each paragraph of which might be elaborated by teachers and extension lecturers to almost any extent. This course has its dangers, however. In my efforts to treat the subject on a non-commercial basis I have been vague and general in some of my mechanical suggestions; and vague- 
ness and generality are the bane of a good deal of our agricultural teaching. In this paper I am trying to avoid controversy on technical points and to focus attention on the importance of the subject and the possibilities it opens up. There is a reason based on experience back of every practical suggestion of what to do and what not to do, what to select and what to avoid.

This pamphlet is not going to farmers or other possible purchasers of equipment. It is going to teachers in agricultural colleges, experiment station and extension workers, agricultural advisors, editors of farm papers, and others directly and professionally responsible for the shaping of the broad lines of agricultural policy; also to bankers and the various commercial, religious, and philanthropic organizations which are trying to help the nation by helping farming and farm living.

For this reason I can speak plainly in this introduction about some of the frauds and abuses of which the farmer is the victim. I have attempted to do this to the farmer himself in catalogues, in advertising, and in letters, only to find the people against whom my criticisms were leveled coolly copying my words down to typographical errors. And because there was no higher authority or standard for the farmer to appeal to or for me to appeal to, the frank statement of the truth for the protection of the farmer appeared to be merely one side of an undignified squabble between rivals in business.

It is because the people to whom this pamphlet goes can do what the farmer cannot do-investigate and find out the truth-and because it is their duty to do so, that I call attention to certain abuses which they are in a position to correct; but before doing so I want to make a frank statement of my own experience and my personal or commercial interest along this line so I can be credited for my experience and discounted for my interests. In doing this I shall take the indirect method to get rid of as many personal pronouns as possible.

Suppose you wanted to endow a department of research in this line; how better you train a man than this:

1st-Give him a course in Mechanical Engineering.

2nd-Give him three years in a machine shop as machinist, draughtsman, and machine designer. 
3rd-Give him fifteen years in charge of a public utility plant and let him design and construct a complete gas plant, electric light and power plant, central steam heating plant, ice plant, and water supply plant, and plan and execute a campaign to adapt the service of these utilities to all the needs of the community.

4th-Give him ten years in plumbing and heating contracting and make him take the state examination for master plumbers.

5th-Give him a couple of hundred thousand dollars to spend over a term of eight years in advertising to country people for their farm water supply and mechanical and sanitary problems. Let him cull the market for all types of machinery it affords along this line, select the best, sell them as part of a complete guaranteed system, and stand good for all kicks and failures whether they are due to the faults of the machines or to the mechanical limitations of average country people.

While this process is going on as a successful business, let him start a machine shop and begin the manufacture of a limited line of equipment based on the successes and failures of existing market types. Let him change over from the others to his own as slowly as he pleases, because business is going on just the same and he can afford to test out each machine of his own design by the same rigid test of experience that he has used as a foundation for his own work.

Let him keep this up for eight more years, gradually covering the whole range of requirements for farm power and sanitation.

6th-Give him eight years of farm experience, beginning in a cabin on raw "cut-over land" in a back-woods district with no expert help and no guide except farm papers, farmers' bulletins and the experience of neighboring farmers, and let him find out what the real farming problem is in this way, both without and with equipment for comfortable, healthful, and efficient working and living.

7th-To keep him from getting an "in-growing mind" give him charge of the editorial policy of a daily paper for eight years. Being an advertiser he will have practically every magazine and farm paper in the country to go through and, consciously or unconsciously, he must hook up his own specialized work and thinking with the social, economic, and political problems of the day. 
This would be the "laboratory method" of getting a foundation laid on facts, with the world for a laboratory and people instead of guinea pigs.

It so happens that, more by accident than design, I have had just this laboratory experience, and from the point of vantage, which this evolutionary experience gives me, I can spot almost unerringly the types of equipment foredoomed to failure as they rise up out of nothing, have their brief day, and disappear-with the farmer's money. Like the mule, they have no pride of ancestry and no hope of posterity, but unlike the mule, they do not pay their way while they live and they give a set-back to farm progress by discouraging the buyer and his neighbors from adding new equipment. The good receives a common condemnation with the bad.

In a paper read before the American Society of Agricultural Engineers by Philip S. Rose, Editor of the American Thresherman and Gas Review, on the subject, "The Place and Field of Agricultural Engineering" I find this:

"A recent survey of farm conditions by a government bureau showed that the majority of farm women put running water in the house as the first necessity for making country life more attractive. These are all matters of engineering that must be met in the future. At present they are met very imperfectly through the propaganda of advertisers and ignorant local dealers. Farmers and country life generally can profit as much from well trained agricultural engineers as manufacturing has from mechanical and electrical engineers."

This is pitifully true, but no more pitiful and damaging to farm progress than much of the hack writing that goes into farm papers and farm bulletins, written by people totally unacquainted with a practical knowledge of production or practical results attained in the hands of average farm people. One has only to be familiar with this class of "literature" and the catalogues of dealers in this line to see that the writers have filled space largely by copying statements and cuts from each other and the catalogues of dealers. Hence, we find no agreement on basic facts, but a simple passing along to the farmer of untried theories or the opposing claims of rival manufacturers.

It is hoped that this pamphlet will start a "shake down" which will help in separating the wheat from the chaff and lead to the establishing of certain basic facts and experiences 
which must be adhered to in the design and construction of such equipment if it is to fill its proper place as a foundation of farm efficiency.

Somehow there must be a means of culling out "impure machinery" as well as impure foods and seeds. Machinery must have ancestry-pedigree-as well as live stock, and must be developed like live stock for a specific purpose. We not only need a "Who's Who" in machinery, but a "What's What," for as much trouble can come from poor adaptation as from poor design and quality. As well raise scrubs as put Herefords in the dairy and Jerseys in the feed lot.

Time and "natural selection" will weed out the fit from the unfit, but "artificial selection" saves time and loss. The farm tractor is being developed in the spot light, with pitiless publicity, in practical tests. There is no parallel method of showing up the hosts of inconspicuous failures in a multitude of farm homes.

The head of one of the greatest agricultural colleges in the world recently said to me, "Most of our teachers are twenty-five years behind the time in practical affairs because they have learned all they know from teachers." But these are the "experts" on whom farm papers largely depend, not simply for information in regard to the results of experiment station research, but to give the farmer advice on matters which can be learned only in practical life.

Another source of supply for farm papers is the hack writer who agrees to furnish an article on any subject. He gets his information from anybody's catalogue, usually arranging with the manufacturer for a certain payment for every time he can get the name of his product across in text or cuts.

With only these two sources of information or the manufacturer or dealer with a direct commercial interest to fall back on, and with so many columns to fill, the editor of a farm paper is truly between the Devil and the deep sea.

But no information is better than wrong information. Most editors could get up a pretty effective "Who's Who" and "What's What" book without any extra expense if they would have their advertising solicitors ask for an introduction to members of "engineering departments" or for a trip of inspection through the plants in which the advertised products are "manufactured." Where these do not correspond with the advertising copy there investigation in the interest of the farmer is indicated. 
A board of censors in this department is needed, but in default of such authority it is up to all real friends of the farmer and the farm home to investigate thoroughly all types and brands of equipment before they endorse, approve, or advertise, either directly or indirectly.

\section{XENOPHON CAVERNO,}

February, 1916.

Kewanee, I11.

"Public health is purchasable. Within natural limitations any community can determine its own death rate." If isolated, yes. But the purchase price and the health and death rates can never be independent of the sanitary conditions on the farms from which a community draws its trade and its food supply.

The men who are living $O N$ but not IN our agricultural problem should search their hearts and minds with a solemn sense of responsibility. To them is given the opportunity to become the evangels of a new and better age. 


\section{FARM EFFICIENCY}

\section{How It Depends on Efficient Equipment For Living}

In a Rural Life Survey, covering 21 representative counties in the State of Ohio, conducted by "The Department of Church and Country Life" of the Presbyterian Church, the following facts were developed in regard to farm incomes.

"One-fourth of the farmers studied were highly successful, judging by the return which they received from their labors. They averaged a clear profit of nine hundred dollars apiece, over and above all farm and household expenses. This sum was quite sufficient to improve their farms, support their churches, and educate their children. Another fourth, while not so fortunate, still made enough comfortably to supply their needs. These averaged three hundred dollars clear for a year. So much for one-half of the farmers. ***

"Another fourth of these farmers were but just able to maintain themselves above the poverty line. These had one hundred dollars a year for all their needs above bare living expenses. The remaining fourth farmed at a loss and had no money reward for their labor. Their farms yielded them annual products worth on the average less than eighty-three dollars in excess of the actual cost of production. This sum must be stretched to cover household expenses and all other necessary expenditures of the family. This means that these men must draw upon their capital if they are to remain on the farm. Eventually it means that they will be starved off of the farm. These men who cannot support their families will not be any better able to support a church. The fact that there is a considerable proportion of the farming population not making a living and coupled with it the fact that there is another equal number who are barely able to remain on the farm furnish the first terms in the problem that is conditioning the efficiency of the country church." 
However much these percentages may vary in different parts of the country, they "furnish the first terms of the problem that is conditioning the efficiency" and prosperity of every state in the Union and of the United States of America.

Taking North, South, East and West together, Ohio probably represents a fair average of farm conditions, and the conclusion that half of the farming in the United States is done below cost, if we include a decent American standard of living, is borne out by the figures in the census. Half of our farming is so poor that the average is pulled down to 14 bushels of wheat and 27 bushels of corn per acre. The rational conclusion is that an enormous amount of our farm land is in the hands of people who cannot or will not farm it successfully, and that such people are enabled to cumber the land and hold it out of good production. largely because they are protected from competition with a better type of people by the poor living conditions which they are willing to accept.

Probably there are few things on which more Americans would agree than that the ideal type of American farming is not the landlord and tenant system, nor yet the industrial type, in which laborers do the work and foreman and superintendents furnish the brains, but that it is the family unit type in which hired help is reduced to a minimum.

Granting that this is the ideal toward which we should like to see American farming develop, the next step is to try to discover whether we may shape a course in the stream of economic tendency which will ever approach our ideal, or whether our ideal is hopelessly counter to the current of evolution. Without argument it may be assumed that there is nothing to indicate that either "industrialized farming" or the landlord and tenant system holds the key to the farm efficiency of the future as compared with the independent homeowning family unit, and that there is much that points in the opposite direction.

The conflict between "the highest yield per acre," required by the nation, and "the highest yield per man," desired by the farmer, which was brought about by the invention of farm implements and the opening up of the cheap lands of the west, is rapidly disappearing with the advancing price of farm land. It can be still further reduced if we substitute for "the highest yield per man" "the highest yield per family" by giving the balance of the family more efficient equipment for living and working. Farm implements and cheap land gave 
the farm man a disproportionate advantage in filling and controlling the family pocket book. The high price of farm land, the concentration of population, with more varied demands and closer markets, make possible a "family unit" type of farming in which the men work as many acres as they can handle during seed time and harvest on the standard crops and live stock, and increase the income per man, not by adding more acres to be worked indifferently by more hired men, but by intensive use of a limited number of acres in which the whole family can join.

It is with an intense desire to help in making this latter type of farming profitable and attractive that attention is called to a weak spot in the campaign for agricultural development, which is holding back the offensive of all of those who are operating along the more direct lines of attack.

No human plan succeeds unless there is an ideal toward which effort is directed.

No human effort directed toward an ideal succeeds unless that ideal lies in the line of that "orderly progress of the universe" in which we are swept along.

Fifty years ago the idealist might have dreamed of family, or at least neighborhood, units of arts and crafts which would supply our need for manufactured products and preserve the old system of freedom and individualism. Any plans based on this ideal would have been doomed to failure. The trend of economic evolution did not lie in that direction. No national industrial department headed by a Secretary of Industry, no schools and colleges for industrial research and education, no industrial extension courses and free bulletins, no county industrial advisors, could have stemmed the tide of economic tendency which has swept us irresistably toward concentration in industry.

But if at that time the nation could have grasped the idea of things as they were going to be, if, instead of spending its energy vainly fighting the irresistable flow of the stream, it had guided and controlled the current, it might have shaped the development of our industrial life so that today it would be as efficient in human production as it is in material production.

While American industry has become efficient American agriculture has remained inefficient because our glut of new land has made efficiency unnecessary, but now the practical exhaustion of the agricultural land in the public domain, and 
the pressure of the increased cost of living, make agricultural efficiency a national necessity. "Orderly progress" toward agricultural efficiency can be obtained only by setting up ideals of farm development which seem not only desirable but possible under agricultural and economic laws as we understand them, and by checking up frequently to see if we are actually making headway in the direction of our ideals.

Is it not true that a great deal of our effort to promote efficient agriculture lacks a definite ideal toward which it is directed, and a definite idea of the complete process by which our agricultural knowledge is to be translated into a bounteous food supply which will increase with the increasing demand of the nation?

Now, it is a self-evident fact that the effectiveness of the work of our national Department of Agriculture, our schools and colleges for agricultural education and research, our agricultural extension courses and county agricultural advisors, our agricultural journals and bulletins, our banker-farmer and business men's associations for the promotion of agriculture, is limited absolutely (not exclusively) by the will and ambition and by the mental and physical ability of the actual tillers of the soil, and it is also true that much of our farm land is in the hands of people who are incapable of assimilating and applying the help offered by all of these agencies. But even this hard combination does not release these agencies from responsibility for solving the problem of farm efficiency; it simply shows that more study and effort must be put on the receiving end. If they fail to do this it is an exact parallel to the farmer who has good seed but a poor seed bed, who keeps on sowing the seed and sowing the seed and says, "If it won't grow, it won't; I am not responsible for the soil."

Now, the surest foundation for a bounteous yield, even from good seed, is an accurate knowledge of the characteristics of the soil. In sowing the seed of agricultural efficiency, has sufficient attention been given to the character of the soil and the condition of the seed bed-to farm people and the conditions in which they live and grow?

\section{THE EVOLUTION OF THE FARMER.}

Our homesteading system, by which the great bulk of our agricultural lands passed to private ownership, drew by natural selection the physically rather than the mentally strong. 
The rugged qualities and indifference to hardship, which made the ideal pioneers, are not those which fit a man for the complex problems of modern agriculture.

For generations the smartest and most ambitious boys on the farm have been drawn to the cities because farming has been a matter of physical strength, not of brains, and because the city offered greater rewards and far more attractive living conditions.

The natural selection by which our rented farms have been filled up has led in the same direction. The owner has usually been satisfied with a low return on a safe investment. It takes more investment to equip a farm to attract a high grade tenant who can pay a high rent from increased yield. A low grade tenant can pay a high rent, without requiring additional investment for, equipment, by living on a lower scale.

The advancing price of farm land added another factor which restricted the number of efficient people available for farmers. A man must not only be strong physically, indifferent to the comforts of living, and have a wife of the same kind, but he must have money. There are few people who meet these specifications.

While the trend of evolution has been attracting brain power to the cities and keeping it off of the farms, the conditions of farm living have restricted the efficiency of the brain power actually on the farms, and meanwhile agriculture has developed into a complex combination of physical and economic science which staggers the imagination.

\section{PRESENT CONDITION OF AMERICAN FARMING.}

Consumption of food products is increasing faster than production.

The policy of breaking in new land to increase our food supply is practically at an end.

Increase in farm products must come from increase in yield per acre.

Our average yield per acre of staple farm crops is less than half of that of Europe or our own good farming.

Our own good farmers have proved that by present known methods of farming our average yield might be doubled if the rest of the farmers had the brains and equipment. 
There is no danger that the farmers will get additional brains and equipment fast enough to reduce the profits of farming.

The way to increase farm yields has been established by agricultural colleges and experiment stations. The knowledge of how this can be done has been thrust at the farmers by free bulletins, extension courses, county agricultural advisors, and farm papers.

Enough farmers have responded to show that the information offered is practical and correct. The great bulk of farmers have not responded at all.

In other lines of business people protect by patents, or conceal by secret processes, the methods by which they can double their output.

The great bulk of the farmers refuse to adopt such methods even when the knowledge is thrust at them.

In spite of all of the vast store of information that has been collected and proven out, in spite of all the agencies for placing this at the disposal of the farmer, the average production of corn still stands at about 27 bushels per acre and of wheat at about 14 bushels per acre as it did before the science of agriculture was established. The conclusion is inevitable that something is wrong at the receiving end-the farmer himself.

\section{THE ROAD TO FARM EFFICIENCY.}

The fact that average American farming is inefficient has been established, and the evolutionary process of growth and the present conditions of farm living, coupled with the present demands of efficient agriculture, make the fact of farm inefficiency not only understandable, but inevitable.

To establish this fact and this cause may be but a small fraction of the remedy, but it is the first fraction to which the balance of the remedy must be fitted. The next step is to understand the human requirements of efficient farming: what type of people are needed.

The brain power required for the continuous successful farming of a quarter section of land up to standards which may be called efficient, measured by present agricultural knowledge, is as great as is required for the successful management of a bank, agricultural college, or any other type of business. 
The man who has brains enough to manage such a farm successfully has brains enough to succeed in other lines, and the farm must bid against the city on its merits if it is to attract him or hold him.

The number of men and women who are strong, both mentally and physically, is limited. To them the world is open and farming will not attract them all, and their number is too small to fill the requirements if it did.

Physical deficiency can be supplemented by mechanical equipment and by living conditions which conserve vitality, but there is no mechanical substitute for brains.

Efficient farming today requires brain strength. Proper living and working equipment will open farming to an immense number of men and women who have the brains to succeed but have not the physical ability to stand the fatigue and hardship of farming under the conditions prevailing on the average farm.

If these facts are true they should be given their proper place in all plans for the promotion of agriculture, and their place is near the foundation, in fact, just below it.

More attractive living and working conditions on the farm will attract a higher type of people. A higher type of people working with more efficient equipment will bring higher yields. Higher yields will support a higher type of living, which will attract a higher type of people, and so on. This is a circle with no beginning and no ending, but in it lies the success of all our agricultural effort. Which should come first? - the attractive equipment or the intelligent people? The problem is not so simple as that. Now it will be one, now the other, now a little of both. The first step is to catch the ideal. Ways and means will develop with time and experience.

Even among "successful" farmers there is a similar cycle of progress which should be set in motion as a basis for the advance work of all agencies for promoting good farming. People grow into wanting what they see and what they see their neighbors have. The more they want, the more they will work to get the money to buy it. The more money they make, the more they see that they want, and so on. Now the "by-product" of this process when it gets started on the farm is increased farm yields, which is the object of all our agricultural efforts. This is so even if the things desired are useless. It is doubly so if the things desired promote the at- 
tractiveness and efficiency of farm living and working. The successful farmer who spends his money buying more land than he can handle to the best effect, helps neither himself nor his country, and the added burden is apt to drive both himself and his children from the farm. The successful farmer who spends his money to make his farm more efficient and attractive and so more productive, not only adds to his wealth and that of the nation, he not only holds himself and his family as expert workers on the farm, but he starts among his neighbors that endless chain of wanting and working, and starts it in the direction which leads toward our best ideals of farm living and to national prosperity as well.

Now, what is this "equipment for living," which has the power to make farming so efficient, attractive, and productive? Just how will it help all these other agencies which are trying to help the farmer? Just how will it help the farmer himself? What will it cost? What return will it yield? How is the farmer to learn to select it intelligently and use it effectively?

Before answering these quesitons let us make a sort of soil analysis of the farming situation and see what elements it lacks to make it a good seed bed for all the seeds of agricultural efficiency which have been sown so liberally and have yielded to sparingly.

\section{THE LURE OF THE CITY.}

The lure of the city is a two-faced affair. On the one hand it offers to the young and adrenturous glitter and tinsel, theatres, excitement, dissipation, luxury, fortune. It offers fortune, but seldom delivers. On the other hand, to settled and sensible people, as well as to the tired and the aged, it offers comforts and conveniences which make a strong and legitimate appeal.

\section{THE PULL OF THE PUBLIC UTILITIES.}

These comforts and conveniences which city people have and country people do not, are those furnished by public utilities, water, gas, electric light, electric power, sewerage, transportation,--things which have been developed to high efficiency only in large units to serve large numbers of people in congested districts, 


\section{THE SOCIAL INSTINCT.}

The "isolation of farm living" is given as an important factor in driving the best farmers to town, but this is mixing cause and effect. This "isolation" has been created largely by the moving to town of the best families and the substitution of a low grade of tenants. Is it lonesomeness or weariness that drives the farmer and his wife from the farm? The average retired farmer is a pathetically lonesome figure in town. Ask him why he quit the farm, and nine times out of ten he will reply: "Wife couldn't stand the work." Sometimes it is he himself who breaks down, sometimes the education of the children causes the move, but reaching the limit of "mother's" strength is the usual cause.

\section{WHERE THE BREAK COMES.}

A farm, like an army, breaks down with its commissary and sanitary departments. The slender link of a woman's endurance limits the strength of the chain of farm living. And this link has not been strengthened in the whole march of our boasted civilization. The eyes of the nation have been fixed on our farmers just as they were on our fighting men at the time of the Spanish war. The brass bands did not march at the head of the sanitary and commissary departments, and the result is history. It is the same with our farm living today. The sanitary and commissary departments have made no advance since the days of our great grandmothers. The substitution of the stove for the open fireplace is the last, in fact the only, real improvement in the equipment of the farm home which has been generally adopted.

\section{A ONE-SIDED RECORD.}

Compare this record with that of equipment for the man's work on the farm. Reapers and mowers, riding plows and cultivators, planters and seeders, hay rakes and loaders, feed grinders and wood saws, hay forks and corn elevators, corn binders, manure spreaders, litter carriers, ensilage and fodder cutters, threshing machines, hay balers and corn shellers, milking machines, windmills and pumps. stationary and portable engines and tractors, and literally hundreds of other machines for special crops and conditions.

Nor is this all. National and state governments, colleges, universities, and experiment stations, have employed 
an enormous corps of trained experts and scientists to study soils, seeds, insects, fungi, birds, and beasts; to scour the face of the earth for new grains and grasses, plants and animals; to study feeds and feeding, breeds and breeding; to design barns, dairies, granaries, corn cribs, and silos. All this is good but only half effective, because the farmhouse has not been brought up to the same advanced line. A city man living close to a restaurant and a laundry may class his wife as a luxury. A farmer cannot. When his kitchen breaks down his farm breaks down. The kitchen organization must come first in time and importance.

\section{ASK GENERAL GOETHALS.}

A great deal of our advance work in agriculture is being done on the model of the Spanish war, not of the Panama Canal. How would General Goethals begin if he were given a free hand to put American farming into the highest state of efficiency? He would provide the most comfortable and healthful living conditions before he started on farming operations or even the equipment for the farming. He would make farm living so attractive that those who were there would want to stay, and those who were not there would want to come. He would make farm conditions so healthful and comfortable that the sick-list would be reduced to the minimum and the efficiency kept at the maximum. He would begin with the sanitary and commissary departments.

\section{THE FARMER'S WIFE.}

The work of the farmer's wife is not only hard and exhausting, it is continuous and practically unvarying. The seasonal changes. which relieve the monotony of the outdoor work on the farm do not penetrate to the kitchen. There is the same lugging of water and slops, the washing and ironing, the sweeping and scrubbing, the filling of lamps and making of beds, the sewing and mending, the care of the children, and the everlasting three meals a day. No other class has derived so little from modern progress and invention, in comfort and luxury, in relief from grinding toil, as the farmer's wife. This is a neglect for which the whole nation is paying an awful price in the high cost of living. 
Not only has modern labor-saving invention passed the farmer's wife by, modern sanitation has as well. The stronghold of typhoid fever, dysentery, and all enteric diseases is now in the country. Privies and cesspools distribute diseases through the medium of flies and polluted drinking water. An over-tired body is not resistant to disease. The personal cleanliness required for health is almost impossible without a heated house, a bath tub, and running water. The chill of unheated rooms, the sudden plunge from the heated kitchen to the pump in the yard, the chill from going to the outside privy in winter, and the poisoning of the system from staying away through dread of the exposure, complete the invitation to disease. An overworked body, the presence of disease germs, the lowering of vitality by exposure, the mental depression from the monotonous routine; this is a combination which few farmers' wives escape. Some have the strength to stand up under it; most of them do not.

We recoil from the concentrated misery of the city slums, of the sweat-shops and factories because it is concentrated. We tolerate the great sum of individual miseries on the farm because they are individual. If all of them could be massed before our eyes a cry of horror would go up to heaven. And behind the pity of it lies the economic waste; the crippling of the one great basic industry of our country on which all others depend. And in the individual economic waste, as in the individual misery, we lose sight of the grand total.

\section{A MODERATE PICTURE.}

This picture of farm living is not overdrawn. In some sections a fair proportion of the farms have some of the lifeand health-saving improvements (few real farms have them all), but the number compared with the total number of farms is negligible. No attempt has been made to picture the added discomforts and dangers due to the houses. which in themselves are crowded and unsanitary and generally unfit to live in, or to suggest the not uncommon drain on vitality of bearing and raising a large family of children. It would be easy to paint a much blacker picture and still be within the limits of truth. 


\section{LIFTING A TON OF WATER A DAY.}

Neither is the possible saving in the wear and tear on a woman's life exaggerated. President Joe Cook, of the Mississippe Normal College, in a bulletin of the United States Bureat of Education, makes the rather startling statement that the average farmer's wife has to lift a ton of water a day. Here is how he figures it:

"The getting of the water from the source of supply to the point of application requires more manual labor than any other item of housekeeping. The water for the kitchen has to be lifted from the well, carried to the kitchen, poured into a kettle, poured out of the kettle into the dishpan, and from the dishpan out of doors. This makes six times the water is handled: and a bucket of water containing 2 gallons, with the containing vessel, will weigh 20 pounds. When this is handled six times, the total lifting is 120 pounds. The cooking of three meals a day on a meager allowance of water will necessitate 10 buckets, which will make for cooking alone, 1200 pounds of lifting per day. When to this is added the water necessary for bathing, scrubbing, and the weekly wash. it will easily bring the lift per day up to a ton; and the lifting of a ton a day will take the elasticity out of a woman's step, the bloom out of her cheek, and the enjoyment from her soul."

\section{SUPPOSE.}

Imagine an average farm home without modern improvements and conveniences. Picture to yourself an average farmer's wife as she goes through her daily routine. Follow every step from the time she starts the fire in the frigid kitchen till she lays wearily down the last pair of mended stockings at night. Now by magic transfer her in her sleep into a house with just the plain conveniences; a heating system; running water, hot and cold; a bathroom with lavatory, closet, and bath tub; a sanitary system of sewage disposal; a power plant that not only pumps the water but runs an electric lighting plant with storage battery; a power washing machine and wringer, a power separator and churn, a racuum cleaner, and perhaps an electric flatiron and a little motor to run the sewing machine.

Give her an extra hour to sleep. The kitchen is warm, the water is hot, and she can get breakfast in a jiffy on the 
oil stove. Now picture to yourself her day's work and her day's uplift to body, mind, and soul. It is the difference between losing and winning, between conquering and being conquered. Look at these pictures from the standpoint of efficiency, of humanity, of romance. No magic of Aladdin's lamp could work a greater transformation or bring greater joy and comfort.

\section{THE COST OF A MIRACLE.}

And what would be the cost? A long spell of sickness and first-class funeral would buy the whole plant. The wages of a hired girl, or two weeks of a nurse and doctor would much more than carry the interest on the investment; so would the price of a fair cow or a poor horse.

\section{A PAYING INVESTMENT.}

In addition to the saving in health and strength, in hired help, nursing, medicine, and doctor bills, such equipment affords many other advantages. A good heating system will heat the whole house at less cost than stoves will heat half of it, a sprinkled garden in a dry season may easily save a hundred dollars in groceries. A little water at the right time and in the right spot frequently saves the house from burning. The farmer himself might profit by a good warm bath in winter and a cold one in summer after his day's work. Oil lamps, candles, lanterns, and matches cause most country fires, both in house and barn. Time saved in the house could be spent profitably in the garden or with the poultry or bees. And these outdoor interests would not only be profitable financially, they would introduce the change and variety of interests which break the monotony of living and bring physical health and mental sanity.

\section{THE NEEDS OF FARM WOMEN.}

The basic needs of farm women have been grouped by the United States Department of Agriculture under four heads-The Economic Needs (Report 106), The Social and Labor Needs (Report 103), The Educational Needs (Report 105), and The Domestic Needs (Report 104), and the latter, the domestic needs, must be met before the former can be, because the others all depend on a surplus of time and vitality 
over that required for the routine work of the farm home. A retinue of servants on the farm is neither possible nor desirable, and the number of women available for farmers' wives with iron constitutions, to smash out a day's work without help or conveniences, and have surplus time and vitality for supplying these various needs, is pitifully small.

Important as woman is in the economic side of farming, there is yet another field in which she is more important. The farm home, and farm community, should become a center of social life, of education and refinement, of culture in its best and truest sense, and this cannot be if the choice of farmers' wives is determined by physical characteristics only. Farmers' wives must not be confined to the draught type. They must be more than dual-purpose; they must be multi-purpose. You cannot select for one predominating quality continually without losing on all other qualities, and no class of people can escape degeneration in the higher qualities if its wives and mothers are selected primarily for physical strength.

\section{AMERICANIZING THE IMMIGRANT.}

The American farm must not be abandoned to foreign races just because their women can stand the work and do not demand living equipment up to the American standard. The city slums are due to the isolation of the immigrants from contact with the best type of American living. The children of foreigners have an intense desire to become Americans, to adopt American manners and customs. They copy what they see-in the city too often the ward boss and the women of the street. On the farm, where we need them, and where they ought to go, they should not be substituted for American farmers, they should be mixed with them, and the type of Americans, which they and their children should have around them as their models, should not be limited to the physically strong only. When brought into contact with the best type of American home and community life, the children of foreign born parents become at once a social and economic asset; when set off by themselves they fail necessarily to rise to the American standard of living, and when planted in backward or degenerate communities they become a social liability. It is possible to have country slums as well as city slums. 


\section{THE GOOD OLD DAYS ARE GONE.}

In the old days farming was a life, not a business. There was a community of interest in the family which is lacking in modern farming. The main object of farming was to raise and store up during the summer the supply of food for the balance of the year. Even the fodder crops were not raised to sell, nor were the farm animals. The bulk of these were used for living. The little surplus not required for living was sold for money or traded for the comparatively few things not produced on the farm. Hard and simple as this life was, it brought out the finest type of family life, of independent manhood and womanhood the world has ever seen. All shared in the work of the rush season, all shared in the leisure of the slack season.

It is said of those days that a large family was the most profitable crop a farmer could raise. But the children were partners in a life then, whereas, if kept on the farm today, they are too often mere employes in an industry. Whether for better or for worse, the fact stands out, however, that modern custom has too often made the children a burden, not a help, to the already overworked farm mother.

\section{GIVE THE FARMER'S WIFE A CHANCE.}

With the coming of farm machinery and the cultivation of large areas, the work of the man became a specialized industry. and the woman ran a boarding house for the workers, generally receiving her "board and keep" for her work. In general, the farm woman has about the least economic independence of any of her sex. Any business founded on the political or economic dependence of woman is headed the wrong way.

There is no slack season in running a farm boarding house. Rest, if there is any, must be provided for in the daily schedule. Work for "pin money" or "economic independence" must be done in spare time each day, and with spare health and strength. Give the women on the farm the time and strength to work out their own lines of "specialized industry," and they will work up a volume of business in innumerable lines which will loom large in the aggregate among the great productive enterprises of the world.

The farm papers and farmers' bulletins are filled with suggestions and practical instructions along such lines. All 
that the farmers' wives and daughters need is time to study up methods and markets, and time and health to do the work.

The enormous poultry and egg business of the country, amounting to half a billion dollars annually, and ranking with the iron and steel business, depends almost wholly on the spare time of farm women. By increasing this spare time, the amount of business might be largely increased and more profitable methods of marketing worked up.

\section{FROM PRODUCER TO CONSUMER.}

With the efforts of the Post Office Department and the express companies to bring the producer and consumer together, a new field of profitable enterprise is opened to the women on the farm. Poultry, eggs, fresh and canned vegetables and fruits, pickles, preserves, butter and cheese, honey, and various other products can be sold direct to the consumer. The surplus strength and time, now wasted on work, which might be done by machinery, the surplus health and energy, which good living equipment would bring, would enable the farm women to work up a business of staggering proportions, which would pay back a hundred fold all the cost of equipment. And the full value of cutting out the middleman would not be measured by cutting out his profit. The business relations established between city and country people would grow into personal acquaintance in innumerable cases, with mutual understanding and breadth of rision, instead of the petty feelings of jealousy or contempt founded on ignorance of each other, which exist so largely today. Better living conditions in the country would increase the respect of city people for country people and of country people for themselves, making acquaintance easier and more pleasant, and encouraging visits back and forth.

\section{MAKING GOOD CITIZENS.}

And, as a crowning result of efficient equipment should come leisure, not laziness, not rest necessarily, but leisure to choose rest or work, and if work, what kind of work, leisure to read, leisure to think, leisure to develop a soul.

No nation should be called civilized, no country should be called Christian, in which the minimum standard of living does not provide for a reasonable amount of leisure for every man and woman. No country is safe which does not insure to its 
citizens a margin of time and vitality which is not exhausted in the mere physical struggle for existence. The power to vote, without leisure to read and think, is an unmitigated danger.

\section{STOPPING THE DRIFT TO THE CITY.}

Equipment of the farm home with modern comforts and conveniences would strike at the root of our whole farming problem. It would stop the drift of the owner to town, and the substitution of a tenant who has no interest except to rob the soil of all he can each year. It would check the drift of the farm boys and girls to the towns and cities. A hall bedroom in a city boarding house would not be so alluring compared to the farm home. Thousands of intelligent people in towns and cities would move to the farm if they could be assured of these comforts and labor-saving devices.

With people staying on the farms and people coming to the farms, the isolation of the farm would be decreased. With more farmers available there would be smaller farms and better cultivation, and so still less isolation. Time, money, the mail carrier, the telephone, the automobile, and good roads would complete the annihilation of the isolation bugaboo.

\section{A NATIONAL DANGER.}

Progress is a resultant of two forces. Prove all things, but hold fast that which is good. Our industrial system is building up a great radical force which needs a balance wheel. Living on the land, one's own land, is the best builder of sanity and balance in the world. The industrializing of farming by working large tracts of land with hired help, or even the general adoption of the landlord and tenant system, would change the whole course of our national development. That this is generally appreciated is shown by the almost frantic efforts of the national and state governments to promote agriculture. The result of all these efforts has been pitifully small. They may have checked the decrease in our average yield per acre, but they have scarcely started an increase, and we are still only 50 per cent efficient on the average compared with European agriculture or our own good farming. This is not chargeable to the land or to lack of available knowledge. It is due to inefficiency-inefficiency of mind, inefficiency of equipment. The great big hole in efficient equipment 
has been in the equipment of the farm home, the equipment for living. When the conditions of farm living are made efficient and attractive there will be plenty of efficient minded people ready to go back to the land.

\section{EQUIPMENT FOR LIVING.}

A farm needs two types of equipment-equipment for living and equipment for operating. Efficient equipment for living comes first and should include everything that makes farm living healthful and attractive and reduces the wear on vitality to the lowest limit. Such equipment includes good houses, heating, plumbing, water supply, gas or electricity, sewage disposal, power to drive washing machines, vacuum cleaners, small separators, churns, and sewing machines, ice houses or refrigerating machines, sleeping porches, porch screens and awnings, electric fans, electric flatiron, lawns, gardens, orchards, croquet sets, tennis courts, swings, automobiles, pianos, organs and phonographs. Any or all of these, and a great many more such things, may be made the basis of farm efficiency. Whatever adds to the attraction of country living. whatever promotes physical health and mental sanity; whatever reduces the wear and grind of work and saves time for better things, is just as necessary equipment as buildings, live stock, farm implements, or even the land itself. It is not expense, it is basic investment.

\section{MAKING MONEY WITH A MORTGAGE.}

It pays to borrow money to buy good permanent equipment for efficient living and working. "Our trouble has been that there is not enough debt on the American farms. Contrast them with the railroads which represent an investment of $\$ 15,000,000,000$. Yet they are mortgaged up to $\$ 11,000,000$,000 , or nearly 80 per cent. But this indebtedness has meant new equipment, enlarged service, increased efficiency, and more income. Our farms are worth approximately $\$ 40,000$,000,000 and carry debt burdens of barely $\$ 6,000,000,000$, or 15 per cent. With a larger mortgage load they would have a bigger producing power if the money were wisely spent. Our mortgaged farms are more valuable than the unmortgaged. Their average of acreage under cultivation is greater, their yield larger, their equipment better, and their assessment higher." 


\section{THE BANKER'S PART.}

Bankers, and especially country bankers, are taking greater interest in better farming. They frequently encourage the farmer by offering to lend him money for silos or other farm improvements. There is no better way for a banker to benefit his community or lay a foundation for the prosperity of his bank than by helping the farmer to put in firstclass equipment for living, and for doing all possible work by machinery in the most efficient way. Such equipment is not "unproductive investment." The road back to the cash box is not more crooked than it is in the case of a silo, a good barn, tile drainage, or quality live stock.

\section{MINIMUM EQUIPMENT FOR HOUSE AND BARN.}

No farm is equipped for efficient work which does not have a comfortable house with a heater (hot air, hot water, or steam), running water, hot and cold, a complete bathroom, a kitchen sink, laundry trays or slop sink, a lavatory on the first floor if the bathroom is on the second, a sanitary system of sewage disposal, and a power washing machine. These should be classed as necessary equipment for every farm home.

Nor is any farm equipped for efficient work which does not have a plentiful supply of running water conveniently distributed for stock watering, sprinkling, and fire protection.

The cost of this minimum equipment of a high grade type for the average farm will vary from $\$ 700$ to $\$ 1000$ according to the size of power plant and the type of heating system. Taking the larger figure, the interest charge at $6 \%$ will amount to $\$ 60$ per year. Let us consider the direct as well as the indirect ways in which this equipment will earn its carrying charges and pay a cash dividend.

\section{THE NATURE OF FATIGUE.}

No one can draw correct conclusions as to the financial saving which can be effected, by having labor-saving equipment on the farm, without a knowledge of the physiological effects of overstrain and overwork. The human body is constantly in a state of change; nutritive material from the food is carried to the tissues by the blood and waste products from the broken down tissue removed. These waste products are true poisons, but under normal conditions they are eliminated 
by the liver, kidneys, and lungs, as fast as they are produced. Exertion increases the rate of production of these poisons, overexertion increases the amount beyond the ability of the blood and organs of elimination to remove them, and fatigue results from a true poisoning of the system. In this building up and tearing down process a certain variation is possible without ill effects. Tissue may be torn down faster than it is replaced for a limited time without evil effect if effort is followed by repose, in which the lost tissue can be rebuilt.

There are two ways of poisoning the system by the toxins of fatigue, overwork, and overtime-working too hard and working too long hours. The question of how hard a man or woman can work or how many hours they can keep at it and preserve their physical and mental efficiency has been given some attention by physiologists. philanthropists. and efficiency experts as it relates to industrial employment. That is recognized as a proper sphere of expert inquiry for our national and economic protection, and a very instructive summary'has been prepared under the auspices of the Sage Foundation ("Fatigue and Efficiency" by Josephine Goldmark).

\section{FATIGUE ON THE FARM.}

From cover to cover, however, there is no suggestion that the facts be applied to farm conditions. Evidently no scientist or philanthropist has discovered that overtime and overwork exist on the farm, and that the individual cases of fatigue poisoning. with all their train of weariness, suffering, disease. and death, dotted over the country, make a grand total greater than that of city industries, and at a much more vulnerable point in our national life.

\section{FACTS ABOUT FATIGUE.}

While the bulk of this volume refers to conditions in industry, its foundation is laid on facts of human anatomy and physiology, which apply to the whole race. A few random quotations from this book, which should be studied by everyone interested in the problem of improved farm living, follow :

"Not only does tissue manufacture poison for itself in its very act of living, casting off chemical wastes into the circling bloodstream; not only are these wastes poured into the 
blood faster with increased exertion, clogging the muscle more and more with its own noxious products; but finally. there is a depletion of the very material from which energy is obtained. In exhaustion, the organism is forced literally to 'use itself up.' We shall see later how destructive to health this phenomenon of exhaustion is, to which nervous as well as muscular tissue is subject; how long it takes to make good such losses; how exhaustion, indeed, taps the very source of our energies."

"Overstrain in industry is obviously no invention of sentiment or fiction when the chemical nature of fatigue and its complex relations with life are realized. The more we learn of the scientific nature of fatigue, the more it invites us to utilize such knowledge for the improvement of working conditions."

"Our body is not constructed like a locomotive which consumes the same quantity of coal for every kilogrammetre of work. When the body is fatigued, even a small amount of work produces disastrous effects. * * * The workman that persists in his task when he is already fatigued not only produces less effective work, but receives greater injury to his organism."

"Monotony often inflicts more injury than greater muscular exertion just because it requires continuous recurring work from nerve centers, fatigue of which, as we have seen, reacts with such disastrous consequences upon our total life and health. The evils of monotony illustrate again how closely all the functions of our life are bound up together; how the physical and nervous and psychic parts of us react and interact upon one another. Aversion from a monotonous grind of work, the effort of the will to 'keep up,' requires just so much more nervous stimulus from already tired nerve centers."

"The relatively slight impairment of efficiency due to overfatigue leads to more serious impairment. Just as minor ailments prove to have an unsuspected importance when considered as gateways to serious illness, so the inefficiency from overfatigue is vested with great significance. Obviously, if overfatigue would be reduced to a minimum, this reduction would carry with it the prevention of the major part of minor ailments, which in turn would lead to a great reduction in more serious illnesses, and this finally would lead to a great reduction in mortality. A typical succession of events is, first 
fatigue, then colds, then tuberculosis, then death. Prevention, to be effective, must begin at the beginning."

\section{THE CASH COST OF FATIGUE.}

These quotatpions have been given to prove that the items of overwork and fatigue cannot be neglected in striking the cash balance at the end of the farm year. They cost money in reduced efficiency, in doctor's bills, in funerals. And it is not only from equipment that saves the body and nerves from fatigue that the cash value from increased health and efficiency comes, it comes also from anything that promotes rest, relaxation, and repose, and allows the body to repair the physical and nervous waste which accumulates during the day on even the best equipped farm.

\section{THE TOTAL COST OF FATIGUE.}

Back of the question of the cost of fatigue-preventing equipment lies still another real question. If you save the cost and keep the fatigue, what have you left? To quote again from the same book:

"Fatigue does mischief negatively as well as positively: lowering vitality and breeding disease is its active and positive aspect. Shutting out the exhausted from their rightful heritage, contracting, binding, inhibiting, is its negative. Other faculties suffer as well as the vital bodily functions. For as exhaustion nullifiies the benefits of better food and shelter, so, too, it paralyses the higher activities, all that feeds men's mental and spiritual needs. The higher standard of living includes besides food and drink and clothing, better education, saner amusements, nobler recreation. But as the over-fatigued digestion fails, so over-fatigued hearing is blunted, overfatigued attention and appreciation flag. Offer what opportunities you will to the exhausted organism, they fall upon literally deafened ears. Fatigue so closes the avenues of approach within, that education does not educate, amusement does not amuse, nor recreation recreate. Books and learning, pictures, music. play-all the enfranchisements of the spirit lose their power."

But even in this flight of idealism the cashable items appear. When through fatigue "education does not educate" in these days of county agents, experiment stations, farm papers. and farmers' bulletins, there is a cash loss of more than $\$ 60$ on any farm in any year. 
Keeping in mind the nature of fatigue and the value, not only of equipment which reduces fatigue, but also of equipment which aids the fatigued body and brain to recover their vigor through rest and relaxation, let us consider the cost and value of the four main items of equipment-Heating, Water Supply, Plumbing, Lighting.

\section{THE HEATING PROBLEM.}

A good heating system is not only a necessity for the protection of water pipes and plumbing fixtures, on which health so largely depends, but it is even more directly connected with the health problem. Sleeping in a cold room may be a good thing, but sleeping in a bed which has absorbed the damp chill of an unheated room is another matter. Heat should be available in every room in the house. To heat the whole house by stoves would cost more than with a heater, and the house would not be well heated at that.

Stoves make work in carrying fuel and ashes, blacking the stove, sweeping and dusting rooms, cleaning rugs and carpets, and washing curtains. The soot and ashes blacken walls and ceilings. This not only takes time and vitality, which might be used at a profit, but it soon calls for a cash outlay to renew rugs, carpets, and curtains, and for repapering and painting. Heat from stoves fluctuates greatly. A moderate, even heat is required to bring about the relaxation of nerves and muscles, which is necessary for the repair of waste tissue and keeping body and brain in fit condition.

A hot air heater is low in price, supplies fresh air, heats up quickly, and supplies much or little heat according to the weather. In a small, compact house it is very efficient. In large houses and where the pipes are of unequal length; it is hard to deliver heat against the wind.

A steam heater will deliver heat anywhere. The piping system and radiation cost less than in a hot water system, but the fuel cost is higher. It is too intense for mild weather, however, and the heat is apt to fluctuate greatly. Steam heat is better adapted to large buildings than to homes.

A vapor system of heating lies between steam and hot water in cost of equipment, cost of fuel, intensity of heat and general fitness for home conditions: 
A hot water system is the best for house heating. The heat can be varied to suit the weather, and the fuel cost is low. It is slow to heat up, but it is slow to cool off also. It requires more head work to lay out the piping system, and it costs more to install than steam or vapor, as it takes more pipe, radiation, and labor.

A hot air, steam, or vapor heater must be set below the rooms to be heated and the piping system must be run in the cellar. No matter how well the pipes are covered the heat is apt to spoil the cellar for the storage of vegetables.

A hot water heater may be set on, or above, the level of the radiators and the hot water pipes distributed to the radiators without going through the cellar. Only the cold water return need come through the cellar. Where there is no cellar or where for any reason the heater and pipes are not wanted in the cellar, a hot water heater may be set in a woodshed or other addition to a house, and waste heat may be used to heat the room.

Heating equipment is so well standardized that local dealers almost anywhere can be depended on to install a satisfactory system.

The cost of a heating system will vary from $\$ 125$ for a small house heated by hot air, to $\$ 300$ for a large house heated by hot water.

\section{WATER SUPPLY.}

The addition of an efficient system of water supply to the farm equipment brings two distinct values. 1st-the saving of time and strength from doing by machinery the hard work which formerly had to be done by hand. It will pay every farmer and his wife to take careful note for a week of the time and strength spent on pumping and carrying water, and measure the value of this time and strength if applied in other ways, including work, rest, reading, and planning. 2nd-the new avenues it opens for health, comfort, and efficiency, including a plumbing system, the sprinkling of lawns and gardens, the washing of floors, vehicles, implements, and live stock, the prevention of fires, the proper watering of live stock.

With good equipment water can be delivered anywhere on the farm at a cost of 3 cents per thousand gallons with gasoline at 18 cents per gallon. The cost of a first class pneumatic water supply system, driven by gasoline engine, will 
vary from $\$ 200$ to $\$ 400$ according to size of farm, number of people, amount of live stock, and other factors.

\section{WATER FOR STOCK.}

The value of having an abundant supply of water stored under pressure in an air tight sanitary tank cannot be overestimated. A large open tank or trough is dangerously unsanitary because the water is liable to be contaminated through the air, through diseased stock, and through the pollution of the well from the mud holes which always surround such tanks. Compare even the best type of stock tank with a number of small metal troughs or drinking bowls distributed at convenient points around the yards and buildings, and supplied automatically with pure, fresh water while the animals drink. The well may be located away from the barnyard where there is no danger of polluting the water. The cost of equipment is small and the gain in efficiency great. A few hundred feet of pipe will bring the water to every point where it is wanted and save time and money every day in the year for a generation. Here again it is not only time and work that are saved. Cattle will not drink the amount of water required for their best development or the greatest milk production unless the water is near them when they want it, and always of a moderate temperature, cooling in summer, and warming in winter. This item alone can be counted on to pay a cash dividend of $\$ 60$ per year from increased production of beef or milk.

To keep barn and hog house floors clean and sanitary requires flushing with water under pressure. A few germs of tuberculosis or hog cholera, left to incubate in cracks and corners, may easily make $\$ 60$ look very small. Hogs should not be compelled to wallow in filth. A concrete hog wallow is of no use unless it is kept sanitary by an abundant supply of clean water. Two cents worth of clean bath water per day will help pay dividends in pork.

Mud and manure should not be allowed to dry on horses and cattle. To keep them clean requires a hose connection at convenient points. If time, clean milk, and healthy live stock, are worth anything, a little cash dividend can be figured for the handy hose connection. 


\section{ARTIFICIAL RAIN}

Irrigation in the region of slack rainfall as the basis of general farming is a specialty and requires a special type of machinery, but there isn't a farm, or even a country home, in the United States, where limited irrigation for a garden would not pay. There are few seasons in which gardens are not delayed in starting or cut short in growth by drought. A few dry weeks in early summer frequently put the garden out of commission for the balance of the season. The expense of installing the underground or overhead pipes for supplying "artificial rain" over a home garden is very small, and one sprinkling at a critical time would frequently pay the whole expense. With a shower available every evening, and with the surplus time and vitality saved by good equipment, any farm family could save $\$ 60$ in groceries and in the sale of extra garden produce, and this figure might be multiplied many times, for yields would be greatly increased and could be counted on every day throughout the growing season, and there is a health value as well as a cash value in eating green things from the garden.

Pigs, lambs, and calves are apt to be permanently stunted by lack of green feed. It will pay any farmer to have a small plot of ground under sprinkler where he can be sure of a pasture of rape or some other green forage crop in spite of drought, and keep his young stock growing. Here again is a reasonable assurance of another $\$ 60$ cash dividend.

In selecting a water supply plant, provision should be made for artificial rain and the machinery should be built to carry a good pressure and produce a fine spray. so that the water will work into the soil gradually and not puddle the surface and cause it to bake in the sunshine.

\section{SELECTING A WATER SUPPLY PLANT.}

There are individual cases scattered all over the country where a farm water supply can be obtained from streams or ponds at a higher level, from flowing streams by rams or water wheels, or from flowing wells, but these cases are so rare compared with the total number of farms that they may be neglected in laying down general rules.

The vast majority of farmers must pump water from wells with a pump driven by a gasoline engine or electric 
motor, and must choose between an elevated tank system, a pneumatic tank system, and a non-storage system.

The best way to approach the selection of a water supply plant is not through the talk of rival salesman, but by considering the points which an ideal water supply system should have.

The following are suggested as the really important points :

First-It should be of such quality and size that it would be ready to respond to the maximum demand every minute of the year.

Second-It should not disfigure the landscape or be exposed to extremes of temperature or the action of the elements.

Third-It should be so located that it will not be a menace to life and property in case of accident.

Fourth-It should be practically indestructible and free from delicate parts.

Fifth-It should be absolutely tight, so that no dust, disease germs, or other foreign substance can get into it.

Sixth-It should keep the water aerated so that it will not become foul or stagnant.

Seventh-It should have sufficient storage and high enough pressure for fire protection.

Eighth-It should be compact and simple, easy to install and easy to operate.

Ninth-It should be quiet in operation.

Tenth-It should be efficient and low in operating cost.

A high grade pneumatic system of water supply fully meets these requirements. If the best type of machinery is selected there is small room for improvement.

\section{PLUMBING.}

Plumbing is a prosaic word, and yet our language is too poor in adjectives to give it proper praise. It is the basis of healthful living. The outside privy is a great menace to health. It is inherently dangerous. Pollution of well water and infection from flies are always probable. The use of earth closets, chemical closets, and the screening of buildings is only a partial protection with the best of care, and the best of care is unusual. Dishwater and slops thrown on the 
ground attract flies and furnish a breeding place for disease germs.

Personal hygiene demands that people be clean inside as well as outside. The inconvenience of going to an outside privy, and the dread of exposure in cold weather are fruitful causes of disease through the absorption of poisons, and the exposure itself is a shock to the system which not only invites pneumonia and kindred diseases, but lowers the vitality which protects from disease of all kinds. The interest charge for plumbing and sewage disposal is about $\$ 15$. It can be depended on to save this in doctor's bills in addition to increasing the earning capacity of the family an indefinite amount.

Not only is plumbing healthful, sanitary, convenient, it is a mental and moral stimulus. It borders on romance and religion. Cleanliness is next to Godliness. A clean bathroom is the best physical expression of cleanliness. It sets a constant mark to live up to.

It is no argument against the necessity of plumbing on the farm that few farm families appreciate its value. Plumbing is an acquired taste. It is one of the latest refinements of civilization, but it is a real necessity, not a useless luxury. People who have never lived with a modern sanitary bathroom look on one as a degenerate luxury. People who have lived with one, always begin with the bathroom when they plan a new house.

Every farmhouse should have a bathroom with clean white walls and fixtures, and a clean white sink in the kitchen. The price of fixtures brings them within the reach of any man who can buy a farm or build a house. The pipe work should be done by a good plumber. It is no work for a bungler or an amateur. The cost should vary between $\$ 150$ and $\$ 200$ according to the type of fixtures and amount of pipe work.

\section{SEWAGE DISPOSAL.}

Plumbing on the farm requires a system of sewage disposal as well as of water supply. Discharge of sewage over the surface of the ground, and even into a stream or lake is always dangerous. It should be prohibited by law and frequently is.

A cesspool collects sewage, it does not reduce and purify it. It is more liable to pollute wells than a privy vault, as the 
large amount of water soaks off into the soil to great distances carrying filth and disease germs with it.

Fortunately modern science and invention have developed a sanitary system of sewage disposal by means of bacteria, which is all but perfect in operation, is easy of construction, low of cost, and requires practically no attention.

Unfortunately, the idea of sewage disposal by means of bacteria caught the fancy of newspaper and magazine writers. who have greatly misrepresented the results obtained and the equipment required.

This free advertising has enabled ignorant and unscrupulous people to claim that when sewage is run into one side of a steel tank, stone jug, barrel, box, or concrete pit, an equal amount of pure water is discharged from the other side, and an analysis by a chemist is frequently offered to prove it. No detailed explanation of the process is offered, and where material is offered for sale, it is strongly intimated that the bacteria required will work only for the seller of the material. This secrecy is due to the fact that if the buyer only understood the process he would know enough not to buy the material offered.

Not only is the equipment offered for sale misleading, but the information on the subject is also. A study of the catalogues of dealers and engineers, articles written for magazines and farm papers, and bulletines issued by colleges, universities and departments of agriculture, shows such a wide difference of design that it is evident that the authors either have different ideas as to what the process is, or very poor judgment in designing suitable equipment.

The principle involved in a bacterial sewage disposal plant is very simple. Certain bacteria, called anaerobes because they thrive only when kept out of contact with air, have the power to reduce vegetable and animal solids to liquids and gases. Certain other bacteria, called aerobes because they thrive only when kept in contact with air, have the power to purify this liquid product produced by the anaerobes, by oxydizing it and reducing it to pure water and harmless gases.

The bacteria necessary for this work exist everywhere, and all that is necessary is to provide the best conditions for them to live and multiply. Without going into details it may be stated that a study of the best books on the subject, of successful and unsuccessful plants, and of patents and the expert testimony in patent suits, where the object is to bring 
out and not to conceal information, lead to the following conclusions:

A farm sewage disposal plant should consist of-

1st-a concrete liquefying tank containing approximately 24 hours' supply of sewage, in which the depth of sewage is maintained at not less than four feet, and from which the sewage overflows into

2nd-a smaller concrete syphon tank in which, whenever the liquefied sewage collects to a depth of about 18 inches, it is discharged by an automatic syphon into

3rd-a tile disposal field consisting of a main line of sewer pipe laid with cemented joints, and of branch lines of drain tile laid within a foot of the surface of the ground, the capacity of the branch lines of tile being greater than the discharge from the syphon tank.

The cost of such a system will be approximately $\$ 100$. The interest charge is $\$ 6.00$, expense and depreciation nothing, if properly designed and constructed.

\section{ELECTRIC LIGH'TING.}

Most farms are out of reach of the electric light wires and must use kerosene lamps or install a gas plant or electric lighting plant. Electric light is universally conceded to be superior to any other method of artificial lighting. It is the safest, requiring no matches and having no flame. It is the most healthful, taking no oxygen from the air and giving off no products of combustion to pollute the air. It is the cleanest, producing no soot and making no air currents which deposit dust on walls and ceilings. It is the easiest to install, as wires can be run almost anywhere, in old buildings as well as new. It is the handiest, as lights can be located out of reach and switches placed wherever most convenient.

Electric power also stands in a class by itself. Motor driven machines need not be grouped around the source of power but can be installed wherever a wire can be run. The smaller machines can be made portable and "plugged in" anywhere on the line, For driving fans, sewing machines, portable vacuum cleaning machines, the electric motor is practically the only suitable power.

Electric flatirons, toasters, chafing dishes, shaving mugs, curling iron heaters, and other small heating derices, are fast becoming household necessities. 
By doing away with the use of matches, candles, lanterns, and oil or gas lamps, the electric current provides what is better than an insurance policy or a fire extinguisher-a prevention of fires.

The kerosene lamp is unhandy. Filling and cleaning take time and strength. It consumes the oxygen in the air and throws off so much heat that it is neither comfortable nor healthful to sit by it. The New York State Health Department reports that 5 per cent of city children and almost 22 per cent of country children have defective vision, and this is laid to the poor lighting of country homes by kerosene lamps. When defective eyesight is thrown into the balance the kerosene lamp becomes more expensive investment than an electric lighting plant.

Until very recently the use of electricity has been a city luxury. The development of the gasoline engine and storage battery made the service of the isolated plant equal to that supplied by the central station. The Tungsten lamp with its low current consumption, reducing the capacity of battery and size of engine and generator required, and the use of low voltage lamps, reducing the number of cells of storage battery required, have brought the price of the plant within reach of the average owner of a farm or country home.

The market is flooded with all sorts of experiments in the line of electric lighting plants for which the farmer is footing the bill. In selecting a plant the following facts should be considered :

Any switchboard can be wired so that the generator can be used as a motor to start the gasoline engine. It is not advisable to do this, however, because it puts a heavy jolt on the battery and is more liable to damage it than a year of ordinary service. A small gasoline engine starts so easily by hand that it takes little more effort than throwing on a switch, and it is good practice to turn the engine over by hand occasionally to see that the compression is good and that all parts are working freely. In electric automobile starters the motor is wired to protect itself and the battery, but this is done at the expense of generator efficiency. A generator, if designed for efficient electric lighting, is not so wired and should not be so used just because it will generally stand the punishment.

The automatic electric starting of a gasoline engine, when the supply of current in the battery is reduced, is an ingenious stunt which multiplies the chances of trouble by many 
hundreds. It is a talking point only. A storage battery does not thrive on frequent charging and discharging, and should be large enough to hold at least two or three day's average supply of electricity. Every gasoline engine should be looked over at least once every day that it runs, so the automatic starting feature is not only a useless but a dangerous complication as it encourages neglect of the care and inspection which is an absolute essential of good service. Constant service should be secured by the size of the battery and not by the frequent starting and stopping of the engine.

A plant of this type which starts every time the lights are turned on without depending on current storage in the battery has reached the height of folly.

The cash return from an electric light plant, and the saving in time and labor and health are not as direct as is the case with plumbing, heating, and water supply, so the electric plant is not listed as necessary equipment. The advantages, however, are so great that it should be installed whenever possible. The average cost of adding the electric plant to the water supply plant will vary between $\$ 300$ and $\$ 400$. including wiring of all buildings and fixtures. The interest charge will be from $\$ 18$ to $\$ 24$ per year. It is worth that as fire prevention only.

\section{GAS}

Gas has one argument over electric lighting. It can be used for fuel as well as light. But a gas stove is little better than a gasoline or kerosene stove, and electric light is superior to gas in every way. Before the invention of the modern low voltage storage battery electric plants, acetylene or gasoline gas plants filled a great need very acceptably. Now, however, it is no exaggeration to say that progress has left them behind.

\section{FARM POWER PLANTS.}

The laying out of a plan for the efficient use of power on the farm is in some ways more complex than the planning of a city power plant. City plants are more standardized, large machinery has commanded a higher type of skill in design and manufacture, and the employment of a consulting engineer is now almost universal. The plants are run by skilled mechanics. Duplicate machinery is usually available 
if anything goes wrong. All these things insure the city home high-grade, continuous service. On the farm the necessity of high-grade, continuous service is much greater than in town. The work is harder and more necessary. There are no hotels, restaurants, laundries, stores, or even near neighbors to fall back on. The loss of service is not all. The time for hunting up trouble and making repairs, cuts into the necessary work on the farm. It is more than the loss of the timeit is a loss also of the other things which should be done in the time. These are days of farming with brains. Success comes with intelligent planning and swift and efficient execution. Loss of time in tinkering up poor machinery, or in doing the work which good machinery would be doing constantly is wasting dollars and saving pennies.

\section{PLANNING IN ADVANCE.}

In figuring on mechanical equipment for the farm, the house power plant should come first because living comes before making a living. The barn or shop plant comes next, with pump, wood saw, feed grinder, emery wheel, grindstone, drill press. Sometimes one plant will take care of both house and barn, sometimes two give better results, but in any case every farmer should have a plan covering every possible application of power to his present and future requirements, and every machine he buys should fit into the plan so that nothing would have to be thrown away. A manufacturing or public service plant which does not follow this plan "goes broke" or changes managers.

When the plan is adopted it should not be handicapped by including inefficient machinery, or the inefficient arrangement or location of equipment and buildings acquired before the plan was adopted.

The location of the well is frequently the greatest stumbling-block in getting the most efficient arrangement of a farm power plant. Most farm wells are located in, or near, the barnyards for direct delivery of water to troughs or tanks for stock watering. As a matter of health of man and beast, it is dangerous to have wells located close to the barnyards, but this is almost necessary when there is no system of storage and distribution of water through pipes.

Aside from the danger of polluted water, the location of such wells is seldom suitable for a power plant, and the farmer who clings to a well which is poorly located destroys in 
advance the possibility of getting an efficient plant, and lays up trouble and expense for his whole future.

There are two common methods of sidestepping the demand for a new well properly located, one is the placing over the well of a cheap pumping engine, which has no relation to the farm power plant and is subject to neglect and exposure, which insure poor service and a short life; and the other is the attempt to get water out of a well, located at a distance from the power plant, by installing in the well delicate devices to be operated from the distant plant. Where the level of the water is within suction distance of the pump (about 20 feet) a suction pipe can be run underground from the pump to the well, but where the water level is too low for a suction pump, and the well is poorly located for a power piant, it is good economy to put down a new well at a point where the power plant will be most convenient and the well best protected from surface water from barnyards or other sources of pollution.

\section{PLANS FOR FARM POWER PLANTS.}

1-Every farm should have a plan for a power plant, a "mechanical lay-out," to provide for every operation which can be done by machinery at a saving of time and strength.

2-This plan should cover present requirements and a long look into the future, and a drawing, or blueprint, should be made showing the present and future position of each machine.

3-The power should be divided and the different machines grouped around each engine or motor to give the greatest convenience and economy of operation.

4 -It is false economy to drive a small load with a big engine, a big load with a small engine, or to have a machine or set of machines located in an inconvenient position to save buying an extra engine.

5-No regular work, such as pumping or electric lighting should be done with a portable engine.

6-No regular work such as pumping and electric lighting should be done by a cheap engine "built for farmers." Such work is generally done by engines of from one to four horse-power, and in these sizes price competition has been 
so fierce that quality has frequently been cut until they are unfit for continuous service.

7-A "farm type" engine may do for occasional work such as filling silos, baling hay, shelling corn or sawing wood, but even for such service it is generally good business policy to pay a little more and get a "shop type" engine that will be a lifetime investment.

8-A house power plant should never have line-shafts or counter-shafts attached to any part of the frame of the house because the vibration and rumbling will be transmitted to all parts of the house.

9-The different machines to be driven should be grouped compactly around the engine or motor, taking up the least possible space and requiring no special foundations, or expert work in setting up or in lining up of shafts and pulleys.

10-Every machine should be shipped practically ready to be run when the crate is taken off, and should drop into the place reserved for it on the plan without expert work, whether all the machines are bought and installed together or one at a time.

The farmer who has a plan of this kind can throw back on the manufacturer the responsibility for the proper working of his machinery under the exact conditions shown.

\section{"FARM IMPLEMENTS" ARE NOT "MACHINERY"}

The use of power on the farm which has come about with the development of the gasoline engine, brings a sharp dividing line in what is sometimes called "farm machinery"farm implements for field use, and regular power-driven machinery. Farm implements have been developed by a long process of evolution for field conditions only. They are loosejointed and flexible so that they adjust themselves to the inequalities of the ground, but they hold together because they are slow-moving and more or less elastic, and both team and driver protect the implements from excessive strains. The total time which a farm implement is run is generally a very small proportion of the year. To build farm implements like shop machinery or engines would be folly. The weight would be prohibitive, the rigidity impossible, and the high quality of bearings unnecessary for such slow speed and short time use. Nevertheless farm implements are none too good, and 
the farmers waste millions of dollars each year by buying the cheapest thing in sight.

Engines on the farm, power-driven machines on the farm. do not fall into the "farm implement" class just because they go into the country. The speed, the shock, the stress, and the strain are the same as in factory equipment, and they work every day in the year, or at least they should. There is plenty that they should do, that is now done by hand, to keep them busy.

\section{WHAT A GAS ENGINE HAS TO STAND.}

In a $2 \mathrm{H}$. P. gasoline engine, with $4 " x 5$ " cylinder, running 500 revolutions per minute, the piston travels 416 feet per minute, almost five miles per hour. Every point on the crank pin wears on its bushings 196 feet per minute, or almost two and a quarter miles per hour. While running at these speeds, at full load, the piston is hit ten thousand blows of 4400 pounds each hour, and these are taken on the crank pin at a pressure of 1670 pounds per square inch. To stand up under this kind of wear and hammering requires the finest of material, the smoothest of finish, and the most accurate adjustment. An engine "built for farmers," in the farm implement atmostphere, on a manure spreader type of construction, and thrown together and sold at a slight advance over the price of the raw material, will not stand up to its work. If the lathes, planers, drill presses, shapers, and milling machines, on which these engines are manufactured were built like the engines, the whole shop would be "scrapped" in six months and new machinery required. Such equipment and methods would bankrupt any business except farming.

\section{A DANGER IN RURAL CREDITS.}

The chief trouble with the farmer has been less his lack of money than his lack of. judgment in buying, and especially in a systematic plan of buying. Few farmers have enough mechanical knowledge to be good judges of machinery and any system of extending rural credits will open up a big field for loss unless accompanied by intelligent and systematic buying of farm equipment.

As a matter of fact there has been very little engineering and very little conscience in the way the growing demand of the farmer for better and more efficient living equipment 
has been met. Twenty years ago villages and cities were putting in public utility plants of the same general type as those now sold to farmers for private plants. They all had to be paid for and then thrown away and a higher type of equipment substituted. A man living in a city may have a tenthousandth part of a public utility plant at his service. If he lives in the country he should have just exactly as good service from a "private utility plant" one ten-thousandth as large, but this service cannot be had if the quality of machinery is reduced with the size. In fact, the small plant requires better quality because it will have less expert care.

\section{BUYING DREAMS.}

It is not only in judging quality and value that the farmer falls down in buying equipment, he is always buying mechanical impossibilities. If he saw a "new type of horses" advertised that would do twice as much work and eat half as much feed as other breds, that would feed and harness themselves and require no care and attention, he would say as the old backwoods-man did when he saw the giraffe, "Naria, there ain't no sech an animal." But the farmer is continually getting stung on mechanical equipment for which the claims are just as ridiculous, because he doesn't know "there ain't no sech a machine."

It is unfortunate that government and state bulletins still advocate cheap temporary makeshifts in the sanitary and mechanical equipment of the farm, and that much of the advertising to farmers is so misleading as to be practically fraudulent.

In the Bulletin of the U. S. Department of Agriculture on the Domestic Needs of Farm Women, we read, "Many women complain of having been induced to purchase worthless apparatus, while others assert that although their husbands cannot be persuaded to risk any money in new irventions, this attitude would be different toward those which were stamped with Government approval. Writers who realize the obstacles in the way of the Government's standing sponsor for articles manufactured by private concerns ask for an explanation of the general principles involved which might guide them in buying."

The extension of rural credits by one system or another has been endorsed by all the political parties and is sure to 
become a settled policy of government. This interferes with the banker's business. There are pure seed laws and there are government experts who will brand with their stamp of quality and stand sponsor for seeds furnished by one dealer and condemn the seeds furnished by another as lower in quality and unfit for use. This interferes with the seedsman's business.

But there are "obstacles in the way of the government's standing sponsor for articles manufactured by private concerns." What are they? Political? There are laws of mechanics as well as of alfalfa seed. Why not tell the farmer the truth in this department no matter who gets hit?

It is good policy for the farmer to let "new inventions" alone and let someone else do the experimenting. Revolutionary inventions in the mechanical world will not be offered to farmers first. Types of machinery which have not established themselves in the mechanical world should not be tried out on the farm.

\section{GETTING SOMETHING FOR NOTHING.}

A "guide for buying" for the farmer should begin with the following sage advice from Mr. Dooley, "Whiniver annybody offers to give you somethin' f'r nawthin', or somethin' f'r less than it's worth, or more f'r somethin' than it's worth, don't take any chances. Yell f'r a pelisman."

Farmers have recently learned that attaching a gasoline engine to a buggy doesn't make an automobile, at least not the kind they want to buy, but they spent a great deal of money learning the lesson. They have still to learn the same lesson in regard to power equipment for the farm.

\section{EXPERT JUDGING.}

The farmer is not to blame because he is not a judge of machinery any more than the mechanical engineer is that he is not a judge of live stock, but think how the farmers would laugh if a mechanical engineer should buy his stock on the same basis that they buy their power equipment. Suppose he ordered shotes by mail, "sight unseen," because they were valued at $\$ 15.00$ each, but were priced at $\$ 4.98$, suppose he went to town and picked up all the cows he could find for sale cheap. Suppose he bought spider-legged, raw-boned, stiff-jointed, sway-backed horses, blind, spavined, ring-boned, 
and sweenied, without finding out what good horses looked like or acted like, under the impression that a horse was a horse. Wouldn't the farmers laugh? Wouldn't they think he was a "jay" not to get expert advice if he didn't know anything about live stock himself, or at least buy from someone whose standard of values was high enough so that he wouldn't deal in scrub stock? The farmer would take it as an insult to his intelligence to be offered this kind of live stock. The mechanical engineer would take it as an insult to his intelligence to be offered the kind of machinery and equipment that is "built for farmers."

There are live stock breeders who care more for the quality of their stock than they do for the money it brings. They breed quality stuff and get a quality price. Both buyer and seller get a fair and honest value. There are live stock breeders and dealers who impose on the buyer and sell defective or poor quality stock at a quality price. There are stock raisers and dealers who sell scrub stuff at a scrub price and who make no effort to breed up to any standard at all. They breed what they happen to and get what they can.

What the farmer needs to understand is that there are the same classes of men in the machinery line, and that there is scrub machinery and grade machinery and pure bred machinery, and that each has its price, cost and value.

PRICE is what you pay for a thing when you get it. You pay it once.

COST is what you have paid for a thing when you are done with it. It includes original price, running expense, repairs, depreciation, trouble, loss of time, loss of service.

VALUE is what you get out of a thing while you have it. It is measured by economy of operation, freedom from repairs and trouble, constant service and length of life.

High price does not necessarily mean big value, but when low price is put forward as the main selling argument, it is a safe bet that the value is low and the final cost will be high.

The lowest cost and highest value never go together. Good material and good finish cost more than poor material and poor finish, and in any machine that gets regular use, good material and good finish pay back far more than their extra cost.

Improved processes of manufacture may reduce cost, and where the reduction in price is due to this factor, the higher 
priced machine will be driven from the market in time. But the same shop processes and equipment are open to all manufacturers, and where a higher priced machine holds a place on the market against a lower one it is a safe bet that it is because the intelligent buyers are not all dead, and that the cheaper machine actually costs more and gives poorer service. There are $1 \mathrm{H}$. P. gasoline engines on the market that sell for $\$ 70$ and hold a market against engines selling all the way down to $\$ 30$. The ignorant man who goes on his own knowledge, never buys the higher priced engine. From his point of view it would be throwing away money. The man who knows machinery pays the higher price because he knows he will more than get it back in economy of operation, freedom from repairs and trouble, constant service, and length of life. The man who does not know machinery can at least know that there is reason back of the choice of the man who does, and follow him. And he doesn't even need to know the other man. The existence of the higher priced machine on the market in face of competition with cheaper machines shows that the other man exists and is continually making his judgments. This argument applies only to timetried types of machinery like gasoline engines and the standard deep well and suction pumps which have established their fitness to survive in the long course of mechanical evolution. That a new invention or a non-competitive article sells for a high price means nothing. To have the price mean anything to the man who is not a judge of values, it must have held its own against competition.

\section{A GUIDE TO BUYING.}

To obtain ideas which should guide him in the purchase of a water supply or electric lighting plant, the farmer should go into a good public service plant and examine the type of equipment which would be placed at his service if he lived in town. He should notice the compact design, the careful machining and finish, the smooth, quiet running. He should talk to the engineer on the relation between high quality and economy of operation, freedom from trouble, and expense for upkeep and repairs.

All catalogues, salesmen and agents will give him quality talk. Probably his own knowledge of machinery will not enable him to tell how much of this talk is true. Quite likely 
the manufacturer or agent has too little mechanical judgment to know himself. The farmer's best protection will be to make a mental picture of the machinery he saw in the public utilities plant, reduce it to $1-1000$ or to $1-10,000$ of its actual size, and see if the machinery he is considering buying falls into the same class.

The laws of mechanics, of the resistance of materials, of friction, of light, heat, and power are the same in the country as in the city. The same type of machinery that is required for dependable service in a mantifacturing or public service plant is required for dependable service anywhere. To be dependable machinery must not only be good in itself; it must make a dependable combination with the man or woman who runs it, and this dependability is due not only to quality, but to a simplicity of design and construction, which makes the machinery easily understood by unskilled people, so that they can give it intelligent care. There is no substitute for good care and intelligent understanding. This applies to machinery as well as to children and live stock. Whoever buys complex or delicate automatic devices with the expectation of escaping this natural law, buys trouble and loss.

\section{WORKING WITHOUT TOOLS.}

The greatest fallacy in the farm world today is the idea that good living equipment for the farmer, instead of being the basis of efficient living during his active life, should be a reward in his old age after a lifetime of effort, shortened and handicapped for the lack of it. We are so used to this that we do not see its economic waste, its pathos, its tragedy, its grim humor. Think of it-living wastefully the best part of your life, and when you find you can't stand it much longer, getting living equipment to die among. "Some die too late and some too soon," and the vast majority of farmers die too soon for the achievement of even this belated ambition. Suppose the manufacturer should try to make his product first and equip his shop afterward. Suppose the skilled workman should dig in the ditch to earn money to buy tools rather than borrow the money to buy tools and pay his debt out of his higher wages. It would be no more ridiculous or wasteful. The foundation of American industry is spending money before making it, getting the best equipment no matter what it costs, even throwing away good machinery to get the best. 
American farming has lagged behind American industry because it has not learned this lesson. A farmer's home is more than a shelter; it is the most important tool used in his business. Manufacturers are learning that there is value, not only in good equipment, but in healthful surroundings in shop and home, in short hours and reduced fatigue, for their employes. The only reason they have not learned this more quickly and more thoroughly is that they have been allowed to throw away worn out workers instead of keeping them in repair as they do their machinery. If the farmer does this he wears out and throws away his wife and children. And some of them do it.

\section{FARMING AS A BUSINESS.}

In the industrial field the development of machinery has put a premium on the skill, brains, and independence of the few at the expense of the many. The employer is constantly striving to obtain machinery which will enable him to employ a lower and less skilled class of labor. The saving in time and efficiency goes to the employer, not to the man who operates the machine.

On the farm it is different. The farmer is both employer and employe. The efficient use of machinery gives him time to develop his own skill, brains, and independence for his own benefit. The more efficient machinery he has, the less he is dependent on unskilled labor. He does not have to use machinery to make himself so rich that he and his wife can hire servants. He can use it to make himself and his wife so efficient that his family is a self-supporting unit.

A farm power plant should not be a rough toy for the farmer to monkey and tinker with; it should be of the best and most dependable type for continuous service like a public service power plant. The farmer should rise every morning with the certainty that his power plant will do its full assignment of work and leave him free to attend to his own without wasting his time and strength on the work which he power plant should do, or in fixing up defective or balky machinery. A dependable power plant, good for a lifetime of steady service with the labor saving and good living equipment which it makes possible, goes far toward taking the element of chance out of farming and making it a regularly prosperous business. 



\section{LIBRARY OF CONGRESS}

|||||||||||||||||||||||||||||||||||||||||||||

||IIIIIIIIIIIII||

00018996236 